\title{
Lymphatic filariasis in Brazil: epidemiological situation and outlook for elimination
}

\author{
Gilberto Fontes ${ }^{1,2^{*}}$, Anderson Brandão Leite ${ }^{1}$, Ana Rachel Vasconcelos de Lima ${ }^{1}$, Helen Freitas ${ }^{3}$, \\ John Patrick Ehrenberg ${ }^{4}$ and Eliana Maria Mauricio da Rocha ${ }^{1,2}$
}

\begin{abstract}
Since the World Health Assembly's (Resolution WHA 50.29, 1997) call for the elimination of lymphatic filariasis by the year 2020, most of the endemic countries identified have established programmes to meet this objective. In 1997, a National Lymphatic Filariasis Elimination Plan was drawn up by the Ministry of Health of Brazil, creating local programs for the elimination of Bancroftian filariasis in areas with active transmission. Based on a comprehensive bibliographic search for available studies and reports of filariasis epidemiology in Brazil, current status of this parasitic infection and the outlook for its elimination in the country were analysed. From 1951 to 1958 a nationwide epidemiological study conducted in Brazil confirmed autochthonous transmission of Bancroftian filariasis in 11 cities of the country. Control measures led to a decline in parasite rates, and in the 1980s only the cities of Belém in the Amazonian region (Northern region) and Recife (Northeastern region) were considered to be endemic. In the 1990s, foci of active transmission of LF were also described in the cities of Maceió, Olinda, Jaboatão dos Guararapes, and Paulista, all in the Northeastern coast of Brazil. Data provide evidence for the absence of microfilaremic subjects and infected mosquitoes in Belém, Salvador and Maceió in the past few years, attesting to the effectiveness of the measures adopted in these cities. Currently, lymphatic filariasis is a public health problem in Brazil only in four cities of the metropolitan Recife region (Northeastern coast). Efforts are being concentrated in these areas, with a view to eliminating the disease in the country.
\end{abstract}

Keywords: Lymphatic filariasis, Epidemiology, Wuchereria bancrofti, Bancroftian filariasis, Brazil

\section{Review \\ Background}

Lymphatic filariasis (LF) is a debilitating disease with serious social and economic impact. Marked by a wide range of clinical manifestations in humans, it is among the so-called neglected tropical diseases and is more common in disadvantaged populations lacking sanitation services and treated water supply. According to the World Health Organization (WHO), the infection is endemic in 72 countries in Asia, Africa and the Americas, with the number of affected people estimated at 120 million, being 108 million of them being infected with Wuchereria bancrofti and 12 million with Brugia malayi

\footnotetext{
* Correspondence: gilberto.fontes@pq.cnpq.br

1 Universidade Federal de Alagoas, Maceió, Alagoas, Brazil

${ }^{2}$ Universidade Federal de São João del Rei, Campus Centro Oeste, Rua Sebastião Gonçalves Coelho, 400, Divinópolis, Minas Gerais 35501-296, Brazil
} Full list of author information is available at the end of the article or B. timori [1,2]. In the Americas region, the disease is caused exclusively by $W$. bancrofti, with active transmission in Haiti, the Dominican Republic, Guiana, and Brazil $[1,3]$.

Since 1997, when Resolution WHA 50.29 of the World Health Assembly set the year 2020 as the target for LF elimination as a global public health problem, the WHO has been engaged to meet this objective $[4,5]$.

The Global Programme to Eliminate Lymphatic Filariasis (GPELF) was launched in 2000 with the objective to eliminate the disease as a public health problem by 2020 [2]. This programme has adopted a strategy consisting of the following components: (i) to stop the spread of infection (interrupting transmission); and (ii) to alleviate the suffering of affected populations (controlling morbidity).

This paper reviews the epidemiological studies on LF in Brazil, explores the current status of this parasitic disease and the outlook for its elimination in the country. 


\section{Review methodology}

A comprehensive electronic search for available data of LF epidemiology in Brazil was performed. Publications were captured from PubMed and Scielo (Scientific Electronic Library Online) databases. Either one of the following keywords written in English or in Portuguese were used: filariasis, Bancroftosis, lymphatic filariasis, Wuchereria bancrofti, combined to form a phrase with epidemiology, control, elimination, survey and Brazil. The abstracts of the retrieved articles were reviewed, and if they did not explicitly show the surveyed population, diagnostic method, sample size and prevalence, they were excluded. Another search strategy adopted involved bibliographic investigation in library collections of any other type of literature sources, including university theses, unpublished surveys, old journals of Health from Brazil, and reports of the Ministry of Health and WHO, in order to retrieve studies and reports on filariasis distribution and control in the country.

\section{Lymphatic filariasis in Brazil: past}

Otto Wucherer described the first W. bancrofti microfilaria in Brazil in 1866, nevertheless, the first systematic epidemiological studies on the distribution of Bancroftian filariasis in this country were conducted decades later. Studies from 1940 to 1950 in Belém (Northern region) and Recife (Northeastern region) yielded microfilaremia rates of $10.8 \%$ and $9.2 \%$, respectively, characterizing these cities as endemic areas [6,7]. These data led the Ministry of Health of Brazil to launch its National Lymphatic Filariasis Campaign. From 1951 to 1958 a total of 811,361 people were examined, using thick blood film collected nocturnally, and 120,399 specimens of mosquito vectors were dissected [8]. The simultaneous discovery of microfilaremic subjects and infected mosquitoes provided evidence of local LF transmission in 11 cities in different States, with the following prevalences: São José da Ponta Grossa (Santa Catarina State), 14.5\%; Belém (Pará), 9.8\%; Barra de Laguna (Santa Catarina), 9.4\%; Recife (Pernambuco), 6.9\%; Castro Alves (Bahia), 5.9\%; Florianópolis (Santa Catarina), 1.4\%; São Luis, (Maranhão), 0.6\%; Salvador (Bahia), 0.4\%; Maceió (Alagoas), 0.3\%; Manaus (Amazonas), 0.2\%; and Porto Alegre (Rio Grande do Sul), 0.1\% [8] (Figure 1).

Bancroftian filariasis in Brazil was an urban phenomenon with focal characteristics and found mainly along the coast. Belém and Recife were considered the cities of greatest epidemiological importance due to their high population density and vector prevalence and density [9].

The National Lymphatic Filariasis Campaign strategy in the 1950s was based on treatment of individually diagnosed patients with diethylcarbamazine [10]. Nearly all foci were considered extinguished, and in the 1980s the Ministry of Health regarded only the cities of Belém and Recife as active areas of transmission in Brazil [11].

\section{Lymphatic filariasis in Brazil: interruption of transmission} in historical foci

Since the national study in the 1950 s, no survey has been conducted to update the information on the geographic distribution of LF all over the country, and the available data were from isolated studies. The entomological surveys conducted since 1990s are summarized in Table 1.

Cases of filariasis infection in Salvador city registered in 1954 were distinguished by clustering of the disease in Uruguai and São Domingos districts [8]. Since then, few studies were conducted to monitor prevalence rates. A city survey carried out in 1958, revealed a prevalence of $0.09 \%$. In 1966, Uruguai district remained the main endemic area in Salvador with $6.2 \%$ microfilaremia rate [20]. The focus has been considered extinguished with no evidence confirming that transmission of the disease has been eliminated in the city [11]. No reports were found on the control measures or epidemiological surveillance activities undertaken to evaluate the elimination of filariasis transmission in the city, unless selective treatment of infected people at the time. Recently, from 2005 to 2009, parasitological, serological, and entomological surveys were conducted in Salvador city to update information on the prevalence of this infection. Night bleed $60 \mu$ l thick blood smear from 7,588 students were tested for microfilaria, and antigen prevalence was assayed in blood samples from 517 children (6-10 years), all were found to be negative [19]. Molecular xenomonitoring to detect filarial DNA in 23,580 female mosquitoes vectors gave negative results. These data meet the current available criteria for absence of transmission in the area. Screening of circulating filarial antigen in blood using rapid immunochromatographic card testing (ICT), and polymerase chain reaction (PCR) for detection of filarial DNA in mosquito vectors, are tools recommended to monitor interruption of $W$. bancrofti transmission [21,22].

In Belém, Northern Brazil, the historical trend in the prevalence of the disease since the first reported cases has been consistently downward. Microfilaria prevalence rates, assessed by thick smears, decreased from $8.2 \%$ in the $1950 \mathrm{~s}$ to $2.6 \%, 0.7 \%, 0.16 \%$ and $0.02 \%$ respectively, over the next 4 decades [17]. Between 1999 and 2004, no autochthonous case was diagnosed among 612,679 people examined across the city [17] (Table 2).

In evaluating LF elimination programs in endemic countries, an area is considered transmission-free when antigenemia, determined by ICT, is less than $0.1 \%$ in a sample of 3,000 children aged 6 to 10 years [5]. In 2003, 


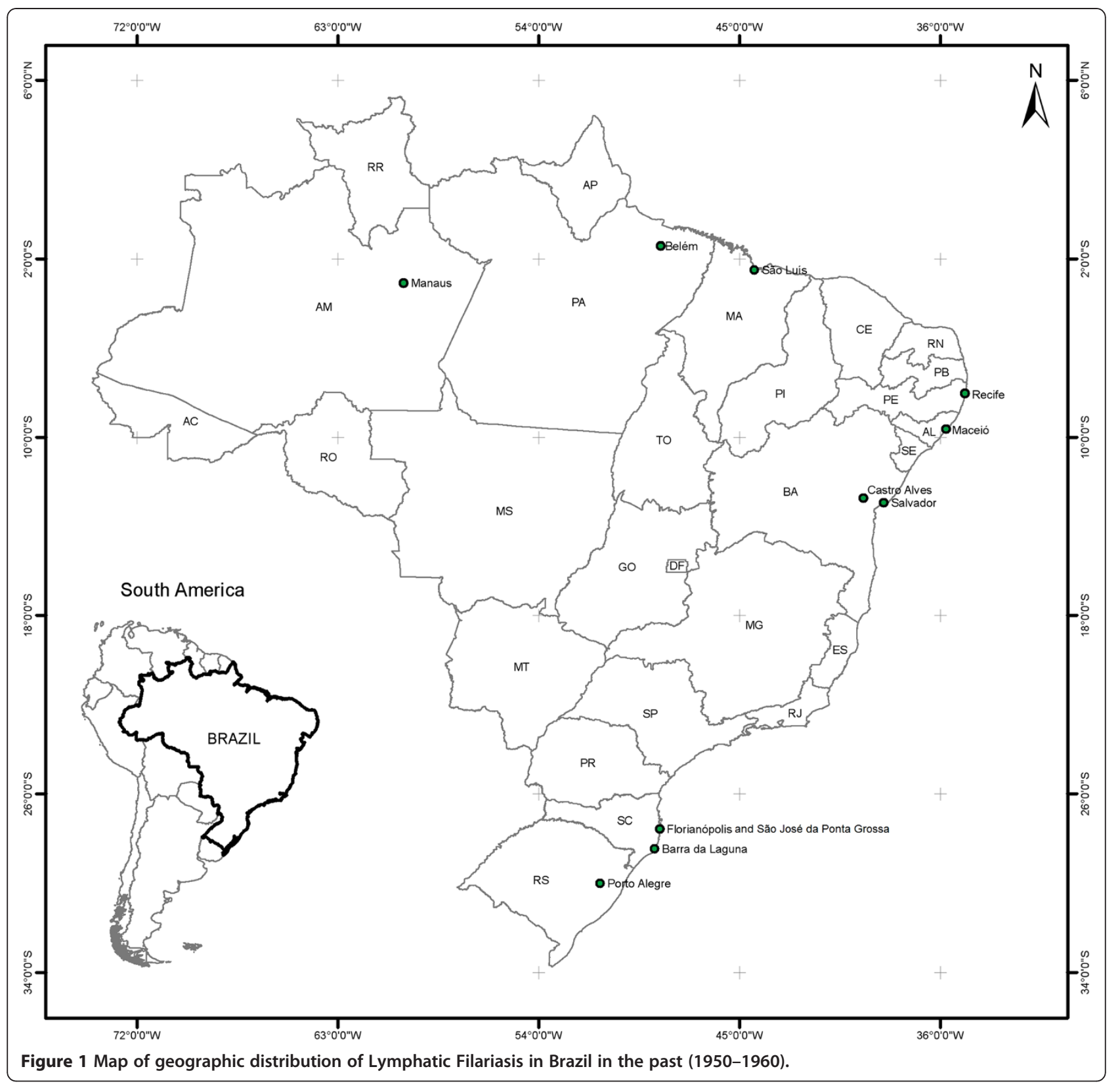

using the ICT, a study was conducted in Belém on a random sample of 3,000 students aged 6 to10 years old in areas historically endemic for Bancroftian filariasis, all tests were antigen-negative [23]. In 2004, another study was conducted in the same area among 2,816 men between 20 to 30 -years old, the most susceptible population to the infection, with ICT negative results [24].

From 2002 to 2004, vectors were captured in 57 out of the 71 districts of Belém. C. quinquefasciatus mosquitoes were examined by dissection $(24,463)$ or PCR $(26,400)$, in the same areas where 164,018 individuals had been tested using the thick blood film technique (50-60 $\mu \mathrm{L}$ blood) [17]. No microfilaremic subjects or infected mosquitoes were found [18]. The data confirm the lack of active transmission in Belém, the only focus of Bancroftian filariasis in the Northern region of Brazil.

In Santa Catarina State in the Southern region, in a 1976 study involving microscopic thick blood analysis, 21,639 residents in the three areas previously identified as endemic were tested, with no positive results [25]. In order to verify elimination of the disease in these foci, 206 residents of São José da Ponta Grossa (90.7\% of the population) and 1,154 of Barra de Laguna (95.2\% of the population) were examined and no cases were detected in areas with prevalences of up to $14.5 \%$ in the $1950 \mathrm{~s}$ [26]. In these same locations 38 treated individuals, 
Table 1 Entomological studies conducted to survey Culex quinquefasciatus females harboring infective Wuchereria bancrofti larvae in historical lymphatic filariasis foci in Brazil

\begin{tabular}{|c|c|c|c|c|}
\hline City/State & Local & $\begin{array}{l}\text { Number of } \\
\text { examined* }\end{array}$ & $\begin{array}{l}\text { Number of females with } \\
\text { larvae } L_{3}(\%)\end{array}$ & Reference \\
\hline Recife/PE & Neighbours of parasitized individuals*** & 7,856 & $48(0.61)$ & [12] \\
\hline Olinda/ PE & Neighbours of parasitized individuals*** & 8,003 & $105(1.31)$ & [12] \\
\hline $\begin{array}{l}\text { Jaboatão de Guararapes/ } \\
\text { PE }\end{array}$ & Neighbours of parasitized individuals*** & 8,010 & $97(1.21)$ & [12] \\
\hline Maceió/AL & Feitosa district & 1,321 & $28(2.1)$ & [13] \\
\hline Maceió/AL & Jacintinho district & 529 & $2(0.4)$ & [13] \\
\hline Maceió/AL & House of parasitized individuals-Feitosa district & 467 & $16(3.4)$ & [14] \\
\hline Maceió/AL & $\begin{array}{l}\text { Neighbours of parasitized individuals-Feitosa } \\
\text { district*** }^{* *}\end{array}$ & 1,426 & $21(1.5)$ & [14] \\
\hline Maceió/AL & House of parasitized individuals- Jacintinho district & 564 & $6(1.1)$ & [14] \\
\hline Maceió/AL & Neighbours of parasitized individuals-Jacintinho*** & 1,403 & $4(0.3)$ & [14] \\
\hline Maceió/AL & House of parasitized individuals-endemic area & 675 & $1(0.15)$ & {$[15]$} \\
\hline Maceió/AL & Parasitized neighbours-endemic area*** & 1,802 & $1(0.055)$ & {$[15]$} \\
\hline São José Ponta Grossa/SC & Random localities & 624 & $0(0.0)$ & [16] \\
\hline Belém/ PA & 57 districts & 24,463 & $0(0.0)$ & {$[17]$} \\
\hline Belém/ PA & 31 historically endemic districts & $26,400^{* *}$ & $0(0,0)$ & [18] \\
\hline Salvador/BA & 22 historically endemic districts & $23,580^{* *}$ & $0(0,0)$ & [19] \\
\hline
\end{tabular}

* Females examined by dissection and microscopy or ** by Polymerase Chain Reaction (PCR).

*** Neighbouring dwellings at 20 meters to the left or right of microfilaremic carriers houses.

diagnosed microfilaremic in the 1950s, were revaluated by different techniques with negative results. Furthermore, none of the 624 captured and dissected C. quinquefasciatus mosquitoes harboured $W$. bancrofti larvae [16]. This data indicates that there is no longer active transmission of Bancroftian filariasis in the historical foci of Santa Catarina.

In Maceió, Alagoas State in Northeastern Brazil, the National Lymphatic Filariasis Campaign of the 1950s, when the prevalence was $0.3 \%$ [27], confined its efforts to treatment of parasitized individuals. Since then, filariasis has been considered as extinguished in the city [11]. However, the discovery of three autochthonous microfilaremic individuals in 1990 [28] triggered a broad epidemiological study in Maceió. A cross-sectional study was conducted and a total of 10,857 night students from every district in the city were evaluated by thick blood smears, with 73 (0.7\%) microfilaremics detected [29].

Table 2 Microscopic blood analysis using night thick blood smears, in the districts of urban Belém, Northern region of Brazil, 1990-2004

\begin{tabular}{lcccc}
\hline Local & Year & Number of individuals examined & Number of microfilaremics (\%) & Reference \\
\hline Greater Belém & $1990-1994$ & $1,062,945$ & $180(0.017)$ & $6(0.002)$ \\
6 Districts & 1995 & 226,796 & $15(0.016)$ & $6(0.004)$ \\
5 Districts & 1996 & 93,498 & $1(0.0008)$ & {$[17]$} \\
4 Districts & 1997 & 133,198 & $0(0.0)$ & {$[17]$} \\
5 Districts & 1998 & 115,279 & $0(0.0)$ & {$\left[(0.001)^{*}\right.$} \\
7 Districts & 1999 & 152,255 & $0(0.0)$ & {$[17]$} \\
6 Districts & 2000 & 132,388 & $0(0.0)$ & {$[17]$} \\
15 Districts & 2001 & 99,093 & $0(0.0)$ & {$[17]$} \\
12 Districts & 2002 & 92,463 & 71,555 & {$[17]$} \\
31 histricts & 2003 & 164,018 & & {$[18]$} \\
\hline
\end{tabular}

* Case of a migrant from a historically endemic area. 
Distribution of the disease proved to be focal, with the infected people concentrated in three central adjacent districts in the city, with prevalences ranging from 1.2 to $5.3 \%$ [29]. In these locations, the captured C. quinquefasciatus mosquitoes exhibited infection rates from 0.4 to 2.1\% [13] (Table 1). Another study was conducted to assess the distribution of filariasis in the general population in Maceió and nine cities in the different physiographic regions of Alagoas State [30]. In Maceió microfilaria status of 10,973 individuals from all age groups were determined through examination of thick smears made from approximately $60 \mu \mathrm{L}$ of finger prick blood, in the three endemic districts the average prevalence of microfilaremics was $2.5 \%$. In the others cities studied no autochthonous cases were found among the 20,103 people tested [30]. However, with the growing migration in the country, there is a risk that the disease might be introduced in areas free of the infection. In Sri Lanka infected migrants have engendered LF in areas where the disease was previously unknown [31]. This occurred also in metropolitan Recife, where cases of the parasitosis appeared in previously unaffected areas $[32,33]$.
In Maceió, in the early 2000s, the natural infection rates of mosquitoes captured in the houses of parasitized individuals and neighbouring houses were $0.15 \%$ and $0.055 \%$, respectively [15]. These rates were lower than those previously obtained in a similar study in the same region [14] (Table 1).

Since the launch of the Lymphatic Filariasis Elimination Program in Maceió in 1999, the population in the endemic area has been continuously monitored to detect and treat parasitized individuals. A complementary antigen study of 3,000 children in 2003, using ICT observing the WHO criteria [5], yielded $10(0.3 \%)$ antigenpositive cases. Despite its low antigenemia, Maceió at that time still had the potential for transmitting Bancroftian filariasis [3].

Epidemiological surveillance in Maceió's endemic area, using 50-60 $\mu \mathrm{L}$ thick blood smears, from 1999 to 2005, has revealed a substantial decline in the frequency of microfilaremia, as follows: $0.74 \%$ (1999); $0.54 \%$ (2000); 0.49\% (2001); 0.10\% (2002); 0.08\% (2003); 0.06\% (2004) and $0.0 \%$ (2005) [34]. The results of blood analysis in Maceió and other cities in Alagoas State from 1990 to 2005 are presented in Table 3.

Table 3 Microscopic analysis using night thick blood smears in Maceió and others cities of Alagoas State, Northeastern region of Brazil, 1990-2005

\begin{tabular}{|c|c|c|c|c|}
\hline City & Local & Number of individuals examined & Number of microfilaremics (\%) & Reference \\
\hline Maceió & Army Military Command & 731 & $2(0.3)$ & [28] \\
\hline Maceió & Students - 33 districts & 10,857 & $73(0.7)$ & [29] \\
\hline Paripueira & Urban area & 2,205 & $2(0.09)^{*}$ & {$[30]$} \\
\hline Maragogi & Urban area & 1,795 & $0(0.0)$ & {$[30]$} \\
\hline Porto Calvo & Urban area & 2,989 & $0(0.0)$ & [30] \\
\hline Marechal Deodoro & Urban area & 2,765 & $0(0.0)$ & [30] \\
\hline Coruripe & Urban area & 2,479 & $0(0.0)$ & {$[30]$} \\
\hline Palmeira dos Índios & Urban area & 2,149 & $0(0.0)$ & {$[30]$} \\
\hline Maribondo & Urban area & 1,975 & $0(0.0)$ & {$[30]$} \\
\hline Piranhas & Urban area & 789 & $0(0.0)$ & [30] \\
\hline Pão de Açúcar & Urban area & 2,957 & $0(0.0)$ & {$[30]$} \\
\hline Maceió & Feitosa district & 2,450 & $133(5.4)$ & [30] \\
\hline Maceió & Pitanguinha district & 1,865 & $43(2.3)$ & {$[30]$} \\
\hline Maceió & Jacintinho district & 4,637 & $50(1.1)$ & {$[30]$} \\
\hline Maceió & Chã da Jaqueira district & 2,021 & $0(0.0)$ & {$[30]$} \\
\hline Maceió & Endemic area (1999) & 2,821 & $21(0.74)$ & {$[34]$} \\
\hline Maceió & Endemic area (2000) & 12,669 & $69(0.54)$ & {$[34]$} \\
\hline Maceió & Endemic area (2001) & 13,544 & $66(0.49)$ & [34] \\
\hline Maceió & Endemic area (2002) & 24,159 & $23(0.10)$ & [34] \\
\hline Maceió & Endemic area (2003) & 7,450 & $6(0.08)$ & {$[34]$} \\
\hline Maceió & Endemic area (2004) & 6,715 & $4(0.06)$ & {$[34]$} \\
\hline Maceió & Endemic area (2005) & 9,425 & $0(0.0)$ & [34] \\
\hline
\end{tabular}

* Non-authochonous cases. 
Since 1990, when systematic and uninterrupted study of LF in Maceió began, 2005 was the first year with no new microfilaremics identified, even when testing 9,425 individuals in the endemic area and its surroundings through thick blood film. Corroborating these data, a cross-sectional survey was performed in 2007 in a random sample of 20,024 night students from 143 schools in the 50 city districts, with no positive exam. From 2005 to 2007, none of the 2,583 vectors examined by PCR were found to be infected [35]. In 2009 an antigenemia research using ICT in 3,000 children was carried out with no positive results. The steps taken have lead to a significant reduction in the number of parasitized individuals to a point where no microfilaremic or infected mosquito could be detected in the past seven years in Maceió, indicating a possible elimination of LF transmission in the city.

\section{Lymphatic filariasis in Brazil: active foci in the present} In Brazil, filariasis continues to be of significant local importance in Pernambuco State, particularly in Recife (capital of the State) and its metropolitan areas, Olinda, Jaboatão dos Guararapes and Paulista (Table 4) [3,33,3639]. Entomological studies showed C. quinquefasciatus infection rates of $0.6 \%$ in Recife and over $1.0 \%$ in the cities of Olinda and Jaboatão dos Guararapes [12] (Table 1). These data indicate that active LF transmission occurred in Recife, and in cities of the metropolitan region. The current program to interrupt transmission of LF in these areas, which comprises $0.8 \%$ of the national population, is based on mass drug administration (MDA), successfully used to control filariasis in some African and Asian endemic countries [40].

Before introduction of control measures blood samples taken for direct parasitological examination (thick blood film) of a sample of 10,581 individuals from 31 districts of Recife, resulted in $6.5 \%$ infected carriers, with district prevalences ranging from 0.0 to $14.6 \%$ [44]. In two of these districts, Coque and Mustardinha, examination of $45 \mu \mathrm{L}$ peripheral blood of 5,563 subjects (5 to 65 years) revealed a microfilaria prevalence rate of $10 \%$ [43]. In the same districts, a study of the pediatric population ( 5 to 14 years), using the same technique showed $6.4 \%$ microfilaria carriers [42].

In a larger parasitological survey conducted with 23,773 Brazilian soldiers from metropolitan Recife, $60 \mu \mathrm{L}$ of blood were examined for microfilaria. A total of $582(2.5 \%)$ of those found to be infected were from areas previously recognized as endemic for LF (Recife, Olinda, Jaboatão dos Guararapes) and also from areas until then considered unaffected (Abreu e Lima, Cabo de Santo Agostinho and Paulista) [32].

In order to map the distribution of LF in metropolitan Recife studies were also conducted in Moreno, Cabo de Santo Agostinho and Paulista, cities surrounded by areas of LF transmission. In Moreno, a rate of $0.08 \%$

Table 4 Microscopic analysis of night thick blood smears, performed in cities of metropolitan Recife, Northeastern region of Brazil, 1990-2011

\begin{tabular}{|c|c|c|c|c|}
\hline City & Local & $\begin{array}{c}\text { Number of individuals } \\
\text { examined }\end{array}$ & Number of microfilaremics (\%) & Reference \\
\hline $\begin{array}{l}\text { Recife Metropolitan } \\
\text { Region }\end{array}$ & Army Military Command & 23,773 & $582(2.5)$ & {$[32]$} \\
\hline Recife & St. Amaro/Campo Grande & 466 & $63(13.5)$ & {$[41]$} \\
\hline Recife & $\begin{array}{l}\text { Coque/Mustardinha distritcs } \\
\text { (children) }\end{array}$ & 1,464 & $93(6.4)$ & {$[42]$} \\
\hline Recife & Coque/Mustardinha districts & 4,597 & $460(10.0)$ & {$[43]$} \\
\hline Recife & 31 districts & 10,581 & $683(6.5)$ & {$[44]$} \\
\hline Olinda & Sapucaia/Salgadinho districts & 685 & $84(12.3)$ & {$[41]$} \\
\hline Olinda & Azeitona district & 541 & $56(10.3)$ & {$[45]$} \\
\hline Olinda & Urban area & 5,258 & $328(6.2)$ & {$[37]$} \\
\hline Jaboatão Guararapes & Cavaleiro district & 9,520 & $213(2.2)$ & {$[36]$} \\
\hline Jaboatão Guararapes & Urban area & 4,367 & $33(0.8)$ & {$[38]$} \\
\hline Jaboatão Guararapes & Urban area & 23,673 & $323(1.4)$ & {$[39]$} \\
\hline Jaboatão Guararapes & Urban area & 8,670 & $96(1.1)$ & {$[46]$} \\
\hline Moreno & Urban area & 2,513 & $2(0.08) *$ & {$[47]$} \\
\hline Cabo St. Agostinho & Urban area & 7,650 & $6(0.08)^{*}$ & [33] \\
\hline Paulista & Urban area & 25,526 & $55(0.22)$ & [3] \\
\hline
\end{tabular}

* Non-autochthonous cases. 
microfilaremia was found, but none of the cases were autochthonous, indicating that filariasis transmission is not a problem [47]. In Cabo de Santo Agostinho, in the late 1990s, an autochthonous case of LF was found. More recently, $0.08 \%$ of the 7,650 examined people had microfilaremia; one of these cases was proven to be autochthonous, indicating the potential for LF transmission in this area [33]. In 2002, microscopic blood analysis in the city of Paulista yielded a $0.22 \%$ microfilaremia rate [3]. This data shows that disease has spread to new places probably due to the migration of infected people.

Before MDA intervention different districts of Olinda showed prevalence rates from 6.2 to $12.3 \%[37,41,45]$.

In Jaboatão dos Guararapes, recently a mean prevalence rate of filarial infection of $2.2 \%$ was observed using thick blood smears examination [36]. Antigen studies in the population aged 19 and below, using the ICT, yielded a $5.5 \%$ positive rate [48]. In this same city $85.7 \%$ of the neighbourhoods presented positive microfilaria carriers, detected by finger prick blood examination, with prevalences ranging from 0.1 to $2.9 \%$ (mean $=0.8 \%$ ). Prior to MDA, in the municipality of Jaboatão dos Guararapes, examination of $50 \mu \mathrm{L}$ of capillary blood of 8,670 children and adolescents (6-14 years old) revealed 96 microfilaria carriers $(1.1 \%)$ and the spatial distribution of microfilaremia showed that 13 (54.2\%) of the 24 districts investigated were positive [46]. Another study showed 323 (1.4\%) individuals were infected among 23,673 of those diagnosed by night thick blood smears. Prevalences up to $25 \%$ stratified by census tracts and analyzed according to socio-environmental and social deprivation indexes, indicated that the greatest risk of filariasis transmission is found in the highrisk strata [39].

Antifilarial MDA, the main strategy recommended by WHO for Lymphatic Filariasis elimination, was launched in Recife in 2003. It involved at first 18,087 people in peripheral population, treated with a single dose of diethylcarbamazine citrate, and had been scaled up in the following years to 141,528 people in 2009 , at a financial cost ranging from U\$ 0.42 to U\$ $0.78 /$ person treated $[49,50]$.

The MDA intervention in the municipality of Olinda started in 2005 and until 2010 43,695 inhabitants were treated [49,51]. A survey conducted in 2007 using ICT detected $66(9.8 \%)$ antigen positive individuals out of 672 school children, indicating active transmission in the evaluated area [52]. Based on these data the Municipal Health Secretary of Olinda expanded MDA, and is making efforts to strengthen health education, social mobilization, morbidity management, and vector control measures [50,51].

According to the document from the Regional Program Manager's Meeting, additional vector control measures in Recife and Olinda are helping to decrease LF prevalence [50].

Jaboatão dos Guararapes has been under MDA program since 2006, but no reports of the post treatment LF prevalence is available.

Of the last four foci describing LF in Brazil, MDA was not introduced only in the municipality of Paulista, because prevalence decreased from $0.25 \%$ in 2002 to $0.008 \%$ in 2010 [49].

\section{Remarks}

In 1997, responding to the resolution of Brazil's National Health Council (Resolution No.190 of 13/06/1996) and WHO's call for the Global Elimination of Lymphatic Filariasis, the Ministry of Health drew up the National Lymphatic Filariasis Elimination Plan (PNEFL) [53]. The main objectives of the PNEFL are: epidemiological reassessment of active foci as well as those considered extinguished; community mobilization; interruption of LF transmission in the endemic foci through specific treatment and vector control; and prevention and reducing disability in affected persons.

With the launch of the PNEFL in Brazil, local programs for the elimination of Bancroftian filariasis were created or implemented in areas of active transmission. Control measures implemented in each endemic area are listed in Table 5 .

Endemic areas detected in the 1950s and not subsequently evaluated are under evaluation to assess if LF has been eliminated in these localities.

From the second half of the 1990s Belém, which had the highest prevalences of LF, have been the object of sweeping environmental sanitation efforts involving the drainage of canals, relocation of wetland populations, and restoration of degraded areas through landfills, treeplanting, and paving.

In Maceió, selective treatment of parasitized individuals and their follow up for at least two years in order to confirm the clearance of microfilaremia, led to elimination of the sources of vector infection since 2004. The data from Belém and Maceió confirm the importance of ensuring the continuity of LF control and elimination programs.

The traditional intervention strategy in Brazil has consisted chiefly of microscopic blood analysis, selective treatment, and care for cases of filarial morbidity. Since 2003, MDA with diethylcarbamazine was undertaken in a sample of the population in endemic areas of Recife and cities of its metropolitan region [54]. The population selected for MDA consisted of residents in LF foci in Recife, Olinda and Jaboatão. In 2003, 18,000 treatments/year were administered, covering a population of 23,400 people [54]. Annual MDA coverage was reported to be $87 \%$ of the 63,800 people who qualified for mass 


\section{Table 5 Intervention and surveillance activities carried out in lymphatic filariasis endemic areas in Brazil}

\begin{tabular}{|c|c|}
\hline City/State & Intervention activities \\
\hline \multirow[t]{12}{*}{ Maceió/Alagoas } & - Training of field and health personnel \\
\hline & - Case-finding (active and passive by microscopic blood examination) \\
\hline & - Determination of microfilaria carriers prevalence (baseline) \\
\hline & - Mapping of endemic foci \\
\hline & - Identification of the population at risk of infection \\
\hline & - Entomological survey \\
\hline & - Selective treatment of microfilaria carriers \\
\hline & - Patients follow up (at least 2 years) \\
\hline & - Medical care to control morbidity \\
\hline & - Antigen test for diagnosis of Bancroftian filariasis in children by ICT \\
\hline & - Xenomonitoring (detection of filarial DNA in mosquitoes by PCR) \\
\hline & - Surveillance (haematological/serological and entomological) \\
\hline \multirow[t]{12}{*}{ Belém/Pará } & - Training of field and health personnel \\
\hline & - Case-finding (active and passive by microscopic blood examination) \\
\hline & - Determination of microfilaria carriers prevalence (baseline) \\
\hline & - Mapping of endemic foci \\
\hline & - Identification of the population at risk of infection \\
\hline & - Entomological survey \\
\hline & - Selective treatment of microfilaria carriers \\
\hline & - Medical care to control morbidity \\
\hline & - Improvement of environmental sanitation \\
\hline & - Antigen test for diagnosis of Bancroftian filariasis in children by ICT \\
\hline & - Xenomonitoring (detection of filarial DNA in mosquitoes by PCR) \\
\hline & - Surveillance (haematological/serological and entomological) \\
\hline \multirow[t]{8}{*}{ Salvador/Bahia } & - Training of field and health personnel \\
\hline & - Determination of microfilaria carriers prevalence (baseline) \\
\hline & - Mapping of endemic foci \\
\hline & - Identification of the population at risk of infection \\
\hline & - Selective treatment of microfilaria carriers \\
\hline & - Antigen test for diagnosis of Bancroftian filariasis in children by ICT \\
\hline & - Xenomonitoring (detection of filarial DNA in mosquitoes by PCR) \\
\hline & - Surveillance (haematological/serological and entomological) \\
\hline \multirow[t]{8}{*}{ São José Ponta Grossa/ Santa Catarina } & - Case-finding (active and passive by microscopic blood examination) \\
\hline & - Determination of microfilaria carriers prevalence (baseline) \\
\hline & - Mapping of endemic foci \\
\hline & - Identification of the population at risk of infection \\
\hline & - Entomological survey \\
\hline & - Selective treatment of microfilaria carriers \\
\hline & - Antigen test for diagnosis of Bancroftian filariasis in children by ICT \\
\hline & - Surveillance (haematological/serological and entomological) \\
\hline
\end{tabular}




\section{Table 5 Intervention and surveillance activities carried out in lymphatic filariasis endemic areas in Brazil (Continued)}

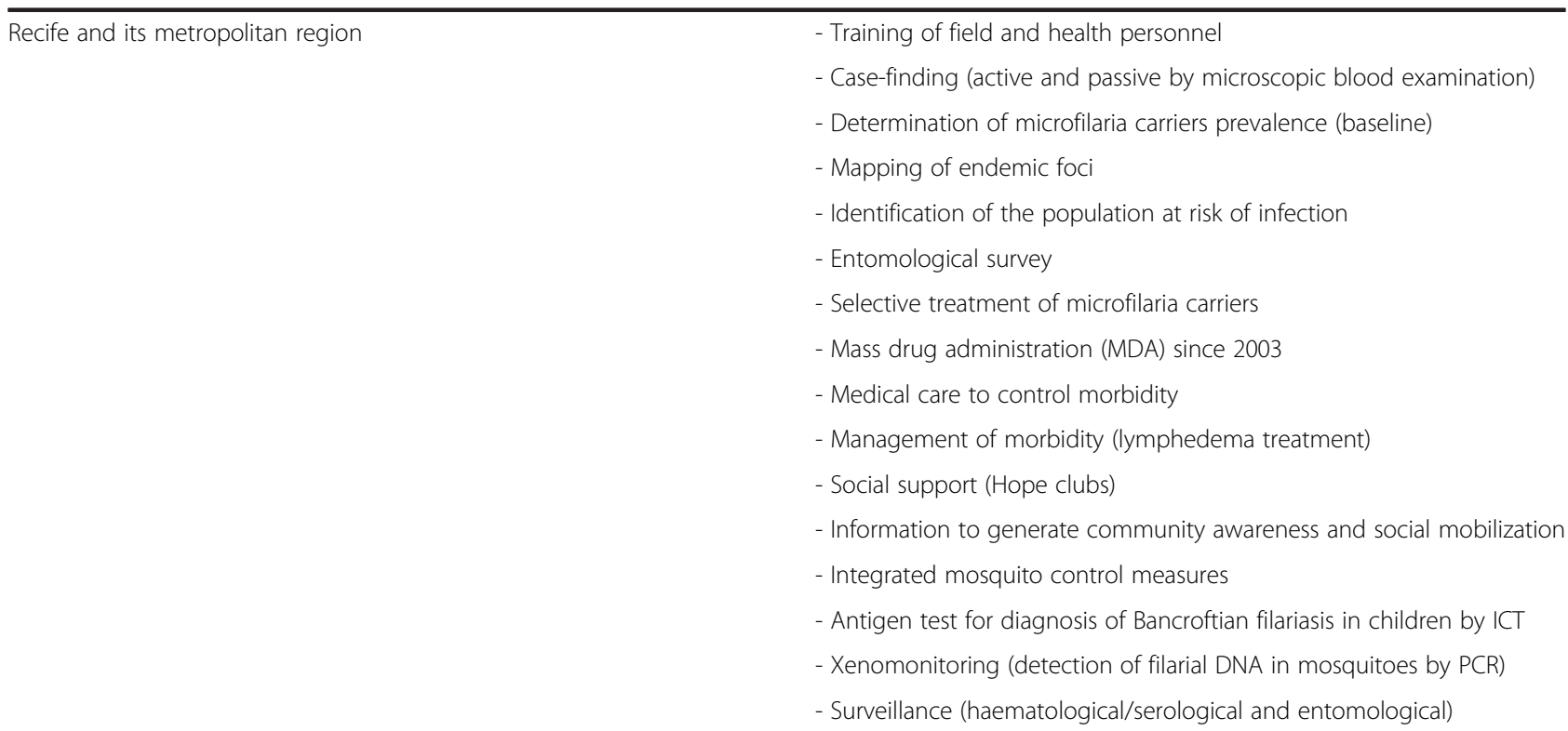

treatment in these areas [54]. To scale up MDA in 2010, 154,056 treatments/year were administered, covering $76.5 \%$ of the population out of 201,385 eligible people [2].

Parasitological and entomological surveillance during the past few years has demonstrated that the transmission of Bancroftian filariasis has been interrupted in Belém, Maceió, Salvador and the three historical foci of Santa Catarina, with no cases found either by microscopic analysis and/or antigenemia assessment. Furthermore, in Belém and Maceió, entomological surveys reported that none of the vector were infected with Wuchereria. Therefore, in Brazil efforts to eliminate the disease should be concentrated in the remaining active foci of LF transmission in metropolitan Recife, freeing Brazil of Bancroftian filariasis according of WHO's global target. Interventions like MDA, vector control, and other actions to control LF must continue in this area to guarantee a steady reduction in endemicity. Considering the biological characteristics of the local vectors, integrated strategy involving MDA and vector control measures could accelerate parasite elimination, reducing the number of years necessary to interrupt parasite transmission. This strategy is more effective in areas where transmission depends on Anopheles instead of Culex species, but in either case helps the sustainability of filariasis transmission interruption [55].

Because of the lack of a gold standard test it is difficult to demonstrate with certainty the interruption of W. bancrofti transmission. However, it is enough to achieve a threshold prevalence below which the parasite transmission is not sustained [21,22].

\section{Conclusion}

Knowledge of the current LF situation in Brazil is essential for implementing joint programs for the elimination of the disease and for setting up epidemiological surveillance programs in locations where microfilaremics are no longer found, to prevent the emergence of new foci and/or reemergence of the disease in areas where it has been eliminated.

Success of the PNEFL and interruption of transmission will prevent the appearance of morbidity such as elephantiasis, hydrocele, and other clinical forms of the disease, as well as its resulting psychological, social, and economic impact.

\section{Competing interests}

The authors declare that they have no competing interests.

\section{Authors' contributions}

GF conceived the idea for the review, analysed data, wrote the initial draft and finalized the manuscript. EMMR analysed data, wrote the initial draft and finalized the manuscript. ABL and ARVL analysed data. HF analysed data and provided critical comments. JPE intellectually supported the study and corrected the drafts of the manuscript. All authors approved the final version of the manuscript.

\section{Acknowledgements}

The authors are grateful to Dr. Steven Ault (PAHO/WHO, Washington DC) for the critical reading of the manuscript, Marcelo Zagonel from Instituto Nacional de Genética Médica Populacional (INAGEMP) for the map and Flávia Mauricio da Rocha Fontes for the English review.

\section{Author details}

${ }^{1}$ Universidade Federal de Alagoas, Maceió, Alagoas, Brazil. ${ }^{2}$ Universidade Federal de São João del Rei, Campus Centro Oeste, Rua Sebastião Gonçalves 
Coelho, 400, Divinópolis, Minas Gerais 35501-296, Brazil. ${ }^{3}$ Secretaria de Vigilância em Saúde do Ministério da Saúde, Brasilia, Brazil. "World Health Organization (WHO - WPRO), Western Pacific Regional Office, Manila, Philippines.

Received: 23 September 2012 Accepted: 1 November 2012 Published: 26 November 2012

\section{References}

1. World Health Organization: Global programme to eliminate lymphatic filariasis. progress report on mass drug administrations in 2007. Wkly Epidemiol Rec 2008, 83(37):333-348.

2. World Health Organization: Global programme to eliminate lymphatic filariasis: progress report on mass drug administration, 2010. Wkly Epidemiol Rec 2011, 86(35):377-388.

3. Pan American Health Organization: Lymphatic filariasis elimination in the Americas. In Proceedings of the $4^{\text {th }}$ Regional Program Manager's Meeting. Maceió: PAHO; 2003:129.

4. World Health Organization: Fifitieth World Health Assembly: resolutions and decisions; annexes. Geneva: Fiftieth World Health Organization (WHA50/ 1997/REC/1); 1997:5-14.

5. World Health Organization: Preparing and Implementing a National Plan to Eliminate Lymphatic Filariasis: A guideline for Programme Managers. In Technical report series. Geneva: WHO/CDS/CPE/CEE/2000.15; 2000:65.

6. Causey OR, Deane MP, Costa O, Deane LM: Studies on the incidence and transmission of filaria Wuchereria bancrofti in Belem Brazil. Am J Hyg 1945, 41:143-149.

7. Azevedo R, Dobin JE: Filariose (Wuchereria bancrofti) no grupo residencial do IAPB no bairro dos Afogados (Recife). Publ. avulsas Inst. Aggeu Magalhaes 1952, 1:157-162.

8. Rachou RG: Conceito e programa de profilaxia da filariose bancroftiana no Brasil. Rev Bras Malariol Doenças Trop 1960, 12:11-40.

9. Rachou RG: Distribuição geográfica das filarioses humanas no Brasil. Rev Bras Malariol Doenças Trop 1957, 9:79-100.

10. World Health Organization: Lymphatic filariasis infection \& disease. Control strategies. Malaysia: Report of a consultative meeting at the University Sains Malaysia Penang; 1994

11. Ministério da Saúde do Brasil: O Controle das Endemias no Brasil (de 1979 a 1984). Brasília: Superintendência de Campanhas de Saúde Pública, SUCAM; 1985:154.

12. Medeiros Z, Dreyer G, Andrade LD, Pires ML, Mendes J, Pimentel R: Wuchereria bancrofti microfilarial density of autochthonous cases and natural Culex infectivity rates in Northeast Brazil. J Trop Med Hyg 1992, 95:214-217.

13. Fontes $G$, Brito $A C$, Calheiros $C M L$, Antunes $C M F$, Rocha EMM: Situação atual da filariose bancroftiana na cidade de Maceió Estado de Alagoas Brasil. Cad Saude Publica 1994, 10:293-300.

14. Calheiros CML: Transmissores em potencial e naturalmente infectados pela Wuchereria bancrofti (Cobbold 1877) em Maceió - Alagoas. In Belo Horizonte. Brasil: M.Sc. Thesis. Universidade Federal de Minas Gerais; 1996.

15. Fontes G, Rocha EMM, Almeida WAP, Medeiros JS, Silva AS: Análise da infecção natural de insetos vetores de Wuchereria bancrofti em área endêmica definida: ações para auxiliar a eliminação da filariose linfática em Maceió-AL. Rev Soc Bras Med Trop 2002, 35(Supp 1):S218.

16. Schlemper BR Jr, Steindel M, Grisard EC, Carvalho-Pinto CJ, Bernardini OJ, Castilho CV, Rosa G, Kilian S, Guarnieri AA, Rocha A, Medeiros Z, Ferreira Neto JA: Elimination of bancroftian filariasis (Wuchereria bancrofti) in Santa Catarina state Brazil. Trop Med Int Health 2000, 5:848-854.

17. Fontes G, Braun RF, Fraiha-Neto H, Vieira JBF, Padilha SS, Rocha RC, Rocha EMM: Filariose linfática em Belém Estado do Pará Norte do Brasil e a perspectiva de eliminação. Rev Soc Bras Med Trop 2005, 38:131-136.

18. Rocha EMM, Almeida WAP, Fontes G, Silva AS, Braun RF, Pimentel LN, Ault SK, Ehrenberg JP: Avaliação epidemiológica do foco de filariose linfática em Belém do Pará. Rev Soc Bras Med Trop 2005, 38(Suppl1):S476.

19. Fontes G, Santos RV, Alves VM, Macedo EC, Freitas H, Baião O, Paranhos M, Rocha EMM: Avaliação da eliminação da filariose linfática na cidade de Salvador-Bahia. Resultados preliminares. Rev Soc Bras Med Trop 2009, 42(Suppl1):S254

20. Sherlock IA, Serafim EM: Condições atuais da filariose bancroftiana no Estado da Bahia Brasil. Rev Bras Malariol Doenças Trop 1967, 19:373-395.
21. Weil GJ, Ramzy RM: Diagnostic tools for filariasis elimination programs. Trends Parasitol 2007, 23:78-82

22. Gass K, de Rochars MVB, Boakye D, Bradley M, Fischer PU, Gyapong J, Itoh M, Ituaso-Conway N, Joseph H, Kyelem D, Laney SJ, Legrand AM, Liyanage TS, Melrose W, Mohammed K, Pilotte N, Ottesen EA, Plichart C, Ramaiah K, Rao RU, Talbot J, Weil GJ, Williams SA, Won KY, Lammie P. A multicenter evaluation of diagnostic tools to define endpoints for programs to eliminate Bancroftian filariasis. PLoS Negl Trop Dis 2012, 6:e1479

23. Braun RF, Rocha RC, Palhano RN, Vieira JBF, Fontes G, Amoras WW: Avaliação da transmissão da infecção pela Wuchereria bancrofti em Belém-PA pelo método de imunocromatografia para detecção de antígenos. Rev Soc Bras Med Trop 2004, 37(Suppl.1):S74.

24. Rocha A, Braun R, Quaresma J, Costa J, Aguiar-Santos AM, Freitas H, Bonfim C, Andrade LD, Oliveira C, Ault S, Medeiros Z: Inquérito antigênico da filariose bancroftiana em Belém do Pará. Verificação da ausência de infecção por Wuchereria bancrofti. Rev Soc Bras Med Trop 2005, 38(Suppl1):S475-S476.

25. Schlemper BR Jr, Ferreira Neto JA: Doenças parasitárias endêmicas em Santa Catarina: I - Filariose. Arq Catarin Med 1985, 14:107-114.

26. Schlemper BR Jr, Ferreira Neto JA, Grisard EC, Coelho CA, Guarnieri AA, Castilho CV, Rosa G, Kilian S, Bernardini OJ, Steindel M: Ausência de reintrodução da transmissão da Wuchereria bancrofti em Santa Catarina. Rev Soc Bras Med Trop 1994, 27(Suppl1):S313.

27. Deane LM, Rosa D, Rachou RG, Martins JS, Costa A, Gomes HM, Carvalho ME: A filariose bancroftiana em Maceió Alagoas: resultado de um inquérito realizado em 1952. Rev Bras Malariol Doenças Trop 1953, 5:17-22.

28. Dreyer G, Medeiros Z, Béliz F, Vergetti G, Vergetti A, Café T, Fontes $G$ : Autochthonous Wuchereria bancrofti microfilaremia in the city of Maceió-Alagoas-Brazil. Mem Inst Oswaldo Cruz 1991, 86:495-496.

29. Fontes $G$, Rocha EMM, Brito AC, Antunes CMF: Lymphatic filariasis in brazilian urban area (Maceió Alagoas). Mem Inst Oswaldo Cruz 1998, 93:705-710

30. Rocha EMM, Fontes G, Brito AC, Silva TRC, Medeiros Z, Antunes CMF: Filariose bancroftiana em áreas urbanas do Estado de Alagoas nordeste do Brasil: estudo em população geral. Rev Soc Bras Med Trop 2000, 33:545-551.

31. Organización Mundial de la Salud: Filariasis linfática: Cuarto informe del Comité de Expertos de la OMS en Filariasis. Serie de Informes Técnicos 702. Ginebra: Organización Mundial de la Salud; 1984:121.

32. Medeiros Z, Gomes J, Béliz F, Coutinho A, Dreyer P, Dreyer G: Screening of army soldiers for Wuchereria bancrofti infection in metropolitan Recife region Brazil: implications for epidemiologic surveillance. Trop Med Int Health 1999, 4:499-505.

33. Medeiros Z, Alves A, Brito JA, Borba L, Santos Z, Costa JP, Espirito Santo ME, Netto MJE: The present situation regarding Lymphatic filariasis in Cabo de Santo Agostinho Pernambuco Northeast Brazil. Rev Inst Med Trop Sao Paulo 2006, 48:263-267.

34. Lima ARV, Leite AB, Barros HCS, Leite RB, Rocha EMM, Fontes G: Perspectiva de eliminação da Filariose linfática em Maceió-Alagoas. Rev Soc Bras Med Trop 2007, 40(Suppl1):S168.

35. Rocha EMM, Fontes G, Almeida WAP, Braun RF, Pimentel LN, Ehrenberg JP, Ault SK: Validation of tools for verification of elimination of transmission $\mathrm{PCR}$ and xenomonitoring results from Belém and Maceió. In $6^{\text {th }}$ Regional Lymphatic filariasis Program Manager's Meeting. San Jose-Costa Rica: PAHO/ WHO; 2005:37-44.

36. Bonfim C, Lessa F, Oliveira C, Evangelista MJ, Santo ME, Meireles E, Pererira JC, Medeiros Z: Situação da filariose bancroftiana na Região Metropolitana do Recife: estudo em uma área endêmica no Município de Jaboatão dos Guararapes Pernambuco Brasil. Cad Saude Publica 2003, 19:1497-1505.

37. Braga C, Dourado I, Ximenes R, Miranda J, Alexander N: Bancroftian filariasis in na endemic area of Brazil: differences between genders during puberty. Rev Soc Bras Med Trop 2005, 38:224-228.

38. Medeiros Z, Bonfim C, Alves A, Oliveira C, Netto MJE, Aguiar-Santos AM: The epidemiological delimitation of lymphatic filariasis in an endemic area of Brazil, 41 years after the first recorded case. Ann Trop Med Parasitol 2008, 102:509-519.

39. Bonfim C, Alves A, Costa TR, Alencar F, Pedroza D, Portugal JL, Medeiros Z: Spatial analysis and privation index to identify urban areas with a high risk of lymphatic filariasis. Trop Med Int Health 2011, 16:748-755. 
40. Molyneux DH, Mwele N, Malecela MN: Neglected Tropical Diseases and the Millennium Development Goals-why the "other diseases" matter: reality versus rhetoric. Parasit Vectors 2011, 4:234.

41. Maciel MAV, Marzochi KBF, Silva EC, Rocha A, Furtado AF: Estudo comparativo de áreas endêmicas de filariose bancroftiana na região metropolitana do Recife Brasil. Cad Saude Publica 1994 10:301-309.

42. Braga C, Albuquerque MFM, Schindler $H$, Rezende A, Maciel A, Silva MCM, Furtado A, Carvalho AB, Lapa T, Ximenes RAA: Perfil epidemiológico da filariose linfática em crianças residentes em áreas endêmicas. J Pediatr 1997, 73:95-100

43. Albuquerque MFM, Marzochi MC, Sabroza PC, Braga MC, Padilha T, Silva MCM, Silva MRF, Schindler HC, Maciel MA, Souza W, Furtado AF: Bancroftian filariasis in two urban areas of Recife Brazil: pre control observations on infection and disease. Trans R Soc Trop Med Hyg 1995, 89:373-377.

44. Maciel A, Rocha A, Marzochi KBF, Medeiros Z, Carvalho AB, Regis L, Souza W, Lapa T, Furtado A: Epidemiological study of bancroftian filariasis in Recife northeastern Brazil. Mem Inst Oswaldo Cruz 1996, 91:449-455.

45. Maciel A, Miranda JC, Irmão Jl, Kobayashi M, Malagueño E: Uma análise prospectiva da filariose linfática em Olinda-PE. Rev Soc Bras Med Trop 2002, 35(Suppl1):S224.

46. Brandão E, Bonfim C, Cabral D, Lima JL, Aguiar-Santos AM, Maciel A, Medeiros Z: Mapping of Wuchereria bancrofti infection in children and adolescents in an endemic area of Brazil. Acta Trop 2011, 120:151-154.

47. Medeiros Z, Oliveira C, Quaresma J, Barbosa E, Aguiar-Santos AM, Bonfim C, Almeida J, Lessa F: A filariose bancroftiana no município de Moreno Pernambuco Brasil. Rev Bras Epidemiol 2004, 7:73-79.

48. Medeiros Z, Oliveira C, Teixeira MJ, Benigno V, Aguiar-Santos AM, Bonfim C: Inquérito antigênico (ICT-Card) para filariose bancroftiana entre crianças e adolescentes no município de Jaboatão dos Guararapes. Rev Soc Bras Med Trop 2005, 38(Suppl1):S472.

49. Ministério da Saúde do Brasil: Reunião de Avaliação do Programa Nacional de Eliminação da Filariose linfática do Brasil. Recife (Pernambuco): Fundação Nacional de Saúde, Brasil; 2010.

50. Pan American Health Organization: Filariasis elimination in the Americas In Proceedings of the $9^{\text {th }}$ Regional Program Manager's Meeting. Washington, DC: PAHO; 2010:90.

51. Rocha A, Marcondes M, Nunes JRV, Miranda T, Veiga J, Araújo P, Tenório W, Aguiar-Santos AM: Programa de controle e eliminação da filariose linfática: uma parceria da secretaria de saúde de Olinda-PE, Brasil, com o Serviço de Referência Nacional em Filarioses. Rev Pat Trop 2010, 39:233-249.

52. Brandão EC, Oliveira PAS, Silva MAL, Mendonca JQ, Barbosa FAMA, Marcondes MMC, Silva SMC, Braga MC, Santos AMA, Rocha A: Frequência da infecção por Wuchereria bancrofti em crianças em idade escolar, em dois bairros de Olinda-PE, pela técnica do cartão ICT. Proceedings of XX Brazilian Congress of Parasitology 2007, 1:56-57.

53. Ministério da Saúde do Brasil: Programa de Eliminação da Filariose linfática do Brasil. Brasília (DF). In Coordenação do Controle de Doenças Transmissíveis por Vetores, Gerência de Endemias Focais. Edited by Ministério da Saúde do Brasil. Brasil: Fundação Nacional de Saúde; 1997.

54. World Health Organization: Global Programme to Eliminate Lymphatic Filariasis. Progress report on mass drug administrations in 2005. Wkly Epidemiol Rec 2006, 81(22):221-232.

55. Bockarie MJ, Pedersen EM, White GB, Michael E: Role of Vector Control in the Global Program to Eliminate Lymphatic Filariasis. Annu Rev Entomol 2009, 55:469-487.

doi:10.1186/1756-3305-5-272

Cite this article as: Fontes et al:: Lymphatic filariasis in Brazil:

epidemiological situation and outlook for elimination. Parasites \& Vectors 2012 5:272.

\section{Submit your next manuscript to BioMed Central and take full advantage of:}

- Convenient online submission

- Thorough peer review

- No space constraints or color figure charges

- Immediate publication on acceptance

- Inclusion in PubMed, CAS, Scopus and Google Scholar

- Research which is freely available for redistribution 